University of Michigan Law School

University of Michigan Law School Scholarship Repository

Articles

Faculty Scholarship

1917

\title{
Prohibiting Advertising on Walls and Buildings Under the Police Power
}

W. Gordon Stoner

University of Michigan Law School

Available at: https://repository.law.umich.edu/articles/1358

Follow this and additional works at: https://repository.law.umich.edu/articles

Part of the Marketing Law Commons, State and Local Government Law Commons, and the Torts Commons

\section{Recommended Citation}

Stoner, W. Gordon. "Prohibiting Advertising on Walls and Buildings Under the Police Power." Mich. L. Rev. 16 (1917): 34-6.

This Response or Comment is brought to you for free and open access by the Faculty Scholarship at University of Michigan Law School Scholarship Repository. It has been accepted for inclusion in Articles by an authorized administrator of University of Michigan Law School Scholarship Repository. For more information, please contact mlaw.repository@umich.edu. 


\section{NOTE AND COMMEN'T}

Prohibiting Advertising on Walls and BuILdinds Under the Police PowER.-There have been many unsuccessful attempts by city authorities of late to abolish or prevent unsightly billboards and advertising. In a recent case $A$ was arrested and fined for violating a city ordinance prohibiting the display of advertising matter on walls and buildings within the city without the consent of the city council. On refusal to pay the fine $A$ was held in the custody of the city marshal, and brought habeas corpus to secure his release. The court held that the affidavit charged no violation of the ordinance unless it were construed as prohibiting the painting of any sign on walls or buildings within the city, and the ordinance, if properly so construed, was 
invalid as constituting a taking of private property for public use without compensation. Anderson v. Shackelford (Fla. 1917), 76 So. 343.

The court in this case refuses to extend the police power to prevent offenses against public taste. In this it is in accord with the consensus of opinion as evidenced by the decided cases, weakened by not a single dissent. Passaic v. Paterson Bill Posting, \&c. Co., 72 N. J. L. 285, 62 Atl. 267; Bill Posting Sign Co. v. Atlantic City, 7I N. J. L. 72, 58 Atl. 342; City of Chicago v. Gunning System, 214 Ill. 628, 73 N. E. I035; People v. City of Chicago, 261 Ill. 16, I03 N. E. 609 ; People v. Murphy, I95 N. Y. I26, 88 N. E. 17. In argument against such limitation of the police power use has been made of the analogy of billboards to smoke, noise and obnoxious odors, which may be prohibited by ordinances enacted under the police power of a city. Rochester v. MacauleyFien Milling Co., I99 N. Y. 207, 92 N. E. 64I ; Glucose Refining Co. v. Chicago, 138 Fed. 209; St. Paul v. Haugbro, 93 Minn. 59, 100 N. W. 470 (smoke); Commonwealth v. Patch, 97 Mass. 22I; Grand Rapids v. Weiden, 97 Mich. 82,56 N. W. 233 (obnoxious odors) ; Goodrich v. Butsse, 247 I11. 366, 93 N. E. 292; New Orleans v. Fargot, IIó La. 370, 40 So. 735 (noises and unsightly buildings and advertising signs); FREUND, PoLICE POWER, sec. I82. There are, however, two respects in which the analogy fails. First, all or nearly all of the cases upholding ordinances enacted under the police power to prohibit odors, noises and smoke, including those above cited, emphasize the deleterious effect of such nuisances on the health of the community, and there can be little doubt that these things cause actual physical discomfort to those offended by them and are injurious to the general health of such persons. Few, if any, esthetes who are offended by the sight of ugly signs will attribute any real physical discomfort or injury to such unsightliness. Second, the group of persons in any community who are offended by the display of inartistic advertising matter is infinitely smaller than the group of those who are offended by noise, bad odors and dense smoke,

The determination of the existence of a nuisance is made to depend upon the presence of actual physical discomfort to persons of ordinary sensibilities, McGill v. Pintsch Compressing Co., I40 Iowa 429, II8 N. W. 786; Wolcott v. Doremus (1917), I0I Atl. 868, and the same test seems to have been uniform. ly applied by the courts where an attempt has been made to prevent the display of unsightly, but not immoral, advertising. The growth of civic pride and the education of the masses in art coupled with a more general belief in the intimate relation between mental contentment and physical wellbeing may work the desired extension of the police power in the future to prevent unsightly billboards and advertisements without abandonment of this test.

The instant case must be distinguished from cases upholding ordinances prohibiting the erection of billboards of a certain kind or in certain localities on the ground that they tend to encourage crime, increase the fire hazard and harbor nuisances dangerous to the public health. St. Louis Gunning Co. v. St. Louis, 235 Mo. 99, 137 S. W. 929 ; Cusack Co. v. Chicago, 267 III. 344, to8 N. E. 340, affirmed, 242 U. S. 526. It must also be distinguished 
from cases declaring valid ordinances prohibiting "museums of anatomy," displaying models, pictures and charts of the human body, as the purpose of such ordinances is clearly the protection of the public morals. Chicago v. Shaynin, 258 I11. 69, I0I N. E. 224.

G. S. 